\title{
The Problem of Africa is Africans
}

\author{
Agbor Charles Nda, Ph.D. \\ History of International Relations \\ Holder of a Diploma in the Administration of Social Security and Human Resources from IRESS-Yaounde. \\ Lecturer and Social Science Researcher \\ University of Bamenda-Cameroon \\ P.O. Box 39-Bambili
}

\begin{abstract}
Of the six continents of the world, the African continent, second largest after Asia has been a school boy to the rest of the other five. Europeans, Asians and many other members of the white race are all claiming to have lessons to teach Africans. Considering Africans barbaric and uncivilized, the civilized and superior race as per say has decided to do and undo with the Africans as it pleases them. Africans are treated as objects or better still as second class citizens from whom nothing fruitful can ever come out. To that effect, this continent has been relegated to the background and forced to shoulder all global burdens and ills. But reading through the history of slave trade and slavery, colonialism and neo-colonialism today, we can affirm with conviction that Africans are responsible for the mischiefs that befalls this continent. This is as a result of the complicity of Africans with the west, the inability of Africans to stand up against western injustice and the egocentric and the inhuman nature of most African leaders. Therefore, it is as a matter of fact for us in this write-up to elucidate on some of the cases where Africans failed to embrace their destiny, but gave their concern to dubious acts of western powers.
\end{abstract}

Keywords; African challenges, African leaders, slave trade, colonialism, neo-colonialism, corruption.

DOI: $10.7176 /$ JAAS/67-05

Publication date:August $31^{\text {st }} 2020$

\section{Résumé}

Des six continents du monde, le continent africain, le second plus vaste après l'Asie a été un élève aux cinq autres. Européens, asiatiques et plusieurs autres membres de la race blanche estiment tous avoir des leçons à enseigner aux africains. Considérant les africains barbares et non civilisés, la race, dit supérieure et civilisée a décidé de faire comme bon lui semble avec ce continent et son peuple. Dès lors, les africains sont traités comme des objets ou encore des citoyens de seconde classe, de qui l'on ne peut s'attendre à rien de fruiteux. A cet effet, ce continent qui a été relégué en dernière position a épaule de force tous les fardeaux et préjudices du monde. Cependant les études sur la traite négrière, le colonialisme et aujourd'hui néocolonialisme, nous amène à affirmer avec conviction que les africains sont responsables des malices qui attaquent ce continent. Ceci est la résultante d'une complicité des africains avec l'Occident, leur incapacité à lutter contre les injustices de l'Occident, puis, l'égocentrisme et la nature inhumaine de la plupart des leaders africains. Fort de ce constat, cette étude a pour but d'élucider certains instances pendant lesquels les africains n'ont pas su prendre leur destin en main, mais ont plutôt collaboré aux actes frauduleuse et malfaisant des pouvoirs occidentaux contre ce continent.

Mots clés : Les défis de l'Afrique, élites africains, la traite négrière, colonialisme, néocolonialisme, la corruption.

\section{Introduction}

Africans are the cause of most if not all of the challenges and troubles that befall this continent since it came into contact with the western world. The errors and wrongs of this people are unavoidably at the center of the difficulties encountered in this continent today. These willful and or ignorant acts are uncountable to the extent that only an encyclopedia can contain details of such individual, collective or organizational mistakes to justify our point of view. But for the purpose of this paper, we are obliged to pick just a hand full of cases to demonstrate this assertion. Results of our findings shall cut across the period of slave trade, colonialism and neo-colonialism. A critical look at criminal acts of some Africans against this continent also orientated this research to think of the way out.

\section{African support to some European misdeeds in the continent}

Some of the moments in the history of this continent where Africans were blind of European evil intensions were during slave trade and slavery and later the balkanization of Africa.

\section{I.1. Africans unequivocal contribution to the mischievous inhuman trade}

Africans were at the fore front of the Trans Saharan and Trans-Atlantic slave trade. It is important to note that the notion of selling and buying of Africans was orchestrated by Africans themselves. Before this sinful and inhuman trade caught western attention, it had gained much ground in the continent as J.D. Fage pointed out in the following quotation;

Except in those parts of West Africa affected by the Arab slave trade across the Sahara, the buying 
and selling of slaves in large numbers, and the deliberate capture of slaves for export, were not normal elements of Negroes life before the coming of European slave traders. But domestic slavery-the possession of relatively small numbers of slaves within the household of free men-seems to have been an accepted feature of society. Human beings could be born into slavery; they could be enslaved in punishment for a civil and criminal offence; they could sell or pledged their kin or even themselves in payment of or as surety for a debt; they could be enslaved as a result of capture in inter-tribal wars... He was for the most part a member of his owner's household, an individual with recognized social rights. He might even on occasion inherit property, and, if a woman, may become the wife of a free man and bear free children... ${ }^{1}$.

Some legendary slave areas were Zanzibar, Dahomey, Ashanti, Sokoto, Bornu, Ethiopia to name just these. The might of kings and their different empires were measured with the number of slaves processed. To maintain or fight for hegemony, these kings passed most of their time attacking and fighting one another to capture and subjugate others as slaves. These slaves that were used for domestic purposes, later became an international "commodity" as kings and other slave dealers later exchange them with salt from the Sahara regions of Tagnaza, Taotek and Taodeni, and copper, cowrie shells, cloth, figs and dates, horses, cattle, aggrey beats and other ornaments from North Africa ${ }^{2}$.

What is amazing here is the fact that it was Africans (the Berbers, Arabs and Jews) of North Africa that were the principal customers from the North. These slaves were bought from Negros Africans of the South in West Africa (Ghana, Mali, Gao, Jenne, Tombouctou and Kano) and taken to Fez and Marrakech in Morocco, Constantine in Algeria, Kairwan or Tunis in Tunisia and Tripoli ${ }^{3}$. The lucrativeness of this inhuman trade let to the raiding of Negro Africa by their brothers of North. Gradually, this ended with the settlement of the latter across and in the region of Sudan in the $13^{\text {th }}$ century. It was in the course of this that European attention was tilted from West Indies to Africa. Therefore, the authors of this crime were Africans as presented bellow;

Except in the very early days of slave trade, or occasionally on parts of the coast where trade was not well developed, it was exceptional for the Europeans slave traders themselves to capture and enslave Africans. The great majority of the slaves carried across the Atlantic were purchased from the merchants and chiefs of the peoples living on the West African coastline. Raids on the coastal people by European traders in search of slaves were rare because they served to antagonize those who were usually only too willing to sell slaves already. The coastal people were willing to sell their fellow Africans into slavery primarily because they wanted European goods and had discovered that the best way to get them was to sell to European traders what they wanted in exchange, and in the seventeenth and eighteenth centuries what Europeans wanted from West Africa above all else were slaves ${ }^{4}$.

According to Joseph Ki Zerbo, Africans were already enslaving one another before the $15^{\text {th }}$ century. From the $15^{\text {th }}$ to $19^{\text {th }}$ century, Europeans merely emulated them. Therefore, the blame of all that Africans incurred during slave trade cannot be shouldered by Europeans but by the Africans themselves because the existence of domestic slavery in Africa had an important bearing on the development of international slave trade ${ }^{5}$.

Unfortunately, the subsequent international slave trade was not like the domestic slave trade. The TransSaharan and Trans-Atlantic slave trade brought untold damages on this continent and its people. It is deplorable looking at the conditions under which these noble and innocent Africans were transported to the coast and later to the Americas. They were marched in long caravans, with each slave having a shackled or rope tied to the next in line. Besides this corporal suffering, slave trade emptied and impoverished the African continent of its human resources as it took only those apt to work in the European plantations. Those European described as beast of labour ${ }^{6}$.

The departure of these Africans signify the lost and separation of love ones. This trade led to the loss of countless lives of Africans as many were killed in raids for slaves, some died on their tedious journey to the coast, others died while awaiting shipment to Europe and those who died on transit from the coast to Europe. Rene Dumont estimated the number to be between 40,000,000 and 100,000,000 African souls perished in the process ${ }^{7}$.

Slave trade and slavery did not only distort the socio-political organization of this continent but also retarded economic advancement. This trade worked against agricultural and industrial development because the labour needed for a sound socio-economic takeoff was shipped to the Western world for the development of their economy. A situation that pushed J.E. Inikori to say without reservation that Africans at that time had all it needed to become a tributary of industrialized economies of the Atlantic zone. The author lamented the fact that instead

\footnotetext{
'J.D. Fage, (1966), An introduction to the history of West Africa, third edition, Cambridge University Press, pp.77-78.

2 J.D. Fage, An introduction to the history of West Africa, p. 9.

${ }^{3}$ Tadeuz Lewicki, (1990), Le rôle du Sahara et des Sahariens dans les relations entre le Nord et le Sud, in Histoire Générale de L'Afrique; L'Afrique du VII au XI siècle, Tome III, UNESCO, pp. 304-305.

${ }^{4} \mathrm{~J} . \mathrm{D}$. Fage, An introduction to the history of West Africa, p. 77.

${ }^{5}$ Joseph Ki-Zerbo, (1978), Histoire de l'Afrique noire d'hier a demain, Paris, Hatier, p. 208.

${ }^{6}$ J.D. Fage, An introduction to the history of West Africa, p. 78.

${ }^{7}$ René Dumont, (1973), L'Afrique noire est mal partie, Imprimerie Bussière, Saint-Amand, p. 23.
} 
of taking advantage of available man power, agricultural and mineral deposits to impose and compete with manufactured goods from the western world, Africans stoop so low to sell themselves as servitudes to the developed world. This was the base of African dependency to the white man ${ }^{1}$.

According to JD Fage, African states like Benin, Ashanti, and Dahomey were not only corrupted by slave trade or were decaying from conflicts engendered by it. The order of the day in these states was fighting one another. This inter African quarrels exposed Africans to Europeans who considered them as barbaric ${ }^{2}$. These and many other ills were the consequences of a trade designed by Africans and used by the Europeans against them.

\section{I.2. African contribution to the balkanization of Africa.}

Here, two main cases of African mistakes that contributed to African sufferings today are our call for concern; African petitions for European protection and African complicity vis-a-vie the partition and exploitation of Africa. With respect to African calls for European colonization in the name of protection, we noticed it was Africans chiefs and kings that wrote letters to invite and sell their sovereignty to western powers. Here is an excerpt of one of the multiple letters written by King Bell and King Akwa of Douala in Cameroon to the Queen of England;

\section{"Dear Madam,}

We your servants have joint together and thought it better to write you a nice loving letter which will tell you all about our wishes. We wish to have your laws in our towns. We want to have every fashion altered, also we will do according to your consul's word. Plenty wars here in our country. Plenty murder and idol worshipers, perhaps these lines of our writing will look to you as an idle tale.

We have spoken to the English consul plenty times about an English government here. We never have answer from you, so we wish to write you ourselves.

When we heard about Calabar River that they have all English laws in their towns, and how they put away all their supersituations, oh, we shall be very glad to be like Calabar, now",

What is astonished in this letter is the fact that these chiefs offered themselves and people as servitudes to the Queen and their desire to have their laws and customs replaced with the English laws. Indeed, these chiefs made themselves and territory a ripe banana for a monkey to eat. According to Dike K. this letters seem to have been inspired by British traders in the territory to influence the foreign office in London to the merchants' request ${ }^{4}$. Confirming it to be true, Tambi Eyongetah and Robert Brain stated that Edward Hewett, the British consul in the years 1879 to 1885 had repeatedly advocated for the formal annexation of the coastal region of Cameroons and was urged by the British government to visit these chiefs and give them friendly messages in order to keep them from surrendering their territory to France or Portugal ${ }^{5}$. This letter was certainly feedback from this visit. However, we think that these Kings should not have feebly signed such an implicative letter and treaty like the one signed with the Germans in July $14^{\text {th }} 1884$, permitting the annexation of Cameroon. This conspiracy was an act of treachery that contributed to open the door of Africa in general and Cameroon in particular for colonialism.

This was the case in many African territories. Many African chiefs or internal collaborators as Louis Ngongo called them ignorantly or willfully signed treaties that enabled Europeans to seized Africa from Africans. It is not surprising that during colonization, most of the traditional rulers pledged their support to the colonial administration and served as servants and auxiliaries of this administration ${ }^{6}$. All these actions sold the continent to world predicators who have drained and are still robbing this continent of its human and natural resources. The above situation was aggravated by the inability of Africans to form a common front during colonization.

\section{I.3. African inability to form a common front against European domination.}

Instead of forming a common bloc against colonialist, African conspired with the white man against one another. One of the glaring cases was in Angola during the struggle for and after independence. After Portugal vehemently refused to grant independence to any of her colonies (Guinea Bissau, Cape Verde, Mozambique and Angola), one would have expected Africans to form a common front to fight for their liberation. Yet, instrumentalised by Russia and the United States, Africans formed arm groups and started fighting with one another. Instead of creating the Angolan liberation movement, they formed Angolan liberation movements. These movements were, the Popular Movement for the Liberation of Angola (MPLA) founded by II dio Machado, Viriato da Cruz, Mario de Andrade and Agostinho Neto, the Front for the National Liberation of Angola (FNLA) led by Holden Roberto, the National Union for the Total Liberation of Angola (UNITA) led by Jonas Savimbi. It is important to say here that like in Nigeria, the configuration of these movement followed ethnic trenches. The FNLA was predominantly in the north

\footnotetext{
${ }^{1}$ J. E. Inikori, (1999), L'Afrique dans l'histoire du monde: la traite des esclaves à partir de l'Afrique et l'émergence d'un ordre économique dans l'Atlantique in Histoire Générale de L'Afrique; L'Afrique du XVI au XVIII siècle, Tome V, UNESCO, p. 136.

${ }^{2}$ J.D. Fage, An introduction to the history of West Africa, p.193.

${ }^{3}$ Victor Le Vine T., (1964), The Cameroons from mandate to independence, Los Angeles, University of California Press, p.20.

${ }^{4}$ Dike K. Onwuka, (1956), Trade and politics in the Niger Delta, 1830-1885, London, p. 216.

${ }^{5}$ Tambi Eyongetah \& Robert Brain, A History of Cameroon, p. 60.

${ }^{6}$ Louis-Paul Ngongo, (1987), Histoire des institutions et des faits sociaux du Cameroun 1884-1945, tome 1, Paris, Berger-Levraut, pp. 126127.
} 
while UNITA in the south and MPLA in the center ${ }^{1}$.

This design shows that these movements were not fighting against the Belgians but Africans fighting Africans. Sooner or later, Portugal, supported by the United States of America used Savimbi of UNITA in the south to fight against the MPLA of Agostinho Nato in the center. Portugal cunningly lured liberation movements in Angola against each other as seen in the following quotation;

"The ability of Lisbon to turn the liberation movements against each other was remarkable. This was especially true of Jonas Savimbi's UNITA. Portugal secretly allowed UNITA's guerilla forces free passage in Angola and also supplied UNITA with arms and ammunition. This was done with the knowledge that UNITA's forces could be used against the MPLA- a bargain which Savimbi faithfully kept"2.

According to a top secret file from Portugal's Direcado General de Seguarance (DGS) dated September 19, 1972 as sited by Victor Julius Ngoh, with this aid, UNITA ambushed his 30 African bothers of the MPLA. Savimbi who pretended he was fighting to liberate Angola, according to the above file, asked the Portuguese authorities for arms, ammunition and medical supplies as well as free passage through Portuguese held areas in Angola to continue to destroy and kill his fellow Africans ${ }^{3}$.

The lack of a common strategy led to confusion, conspiracy and complicity of Africans which intend contributed to European successful domination and ruining of the continent. Besides, it greatly prolonged the liberation struggle in Angola until November 11, 1975 when Lisbon decided to grant independence to this country. The problem of Africa is Africans because immediately at the dawn of independence and the withdrawal of the Portuguese, Angola was plunged into a destructive and useless civil war. This war that lasted for about thirty-five years, claimed about a million dead, about eight hundred displaced. The scenario was the same in Belgian Congo, Nigeria and many other African countries ${ }^{4}$.

\section{Conflicting African ideas and approaches in the struggle for African nationalism}

Conflicting African ideas and approaches in the struggle for African nationalism can be explain using two different instances; conflicting African ideas and approaches in the struggle to reinstate the African identity, African diverse views and approaches over the question of pan Africanism and Africans against African unity.

\section{II.1. Conflicting African ideas and approaches in the struggle to reinstate the African identity.}

Another area where Africans aired was the failure of African leaders to agree on the approach to ascertain the African civilization. Here, we noticed two African elite classes under the banners of Negritude and West African Students' Association (WASU) struggling to restore the lost African identity. Crises of African identity and rights began with European claiming superiority over Africans and black Africans in particular. The whites believed that nothing good has and can ever come from this continent. This cultural assimilation was justified in the past by the French on the wrong ground that Africans had no history or culture of their own. As a means to counter this conception, the French-speaking Africans in Africa and Negroes of West Indies came up with a cultural and political movement against the French policy of assimilation. "Negritude" as this movement was called, was aimed at protecting the cultural and socio-political values of Africa and to demonstrate that, on the contrary, Africans had contributed and are still contributing enormously to the world civilisation ${ }^{5}$.

Some sources say that "Negeitude" began with successful revolution in 1802 by African slaves in Haiti under the African slave leader Toussaint Louverture. This important rebellion overthrew the French rule and brought about the birth of the first Negro republic in the world. Cultural identity among Negros in the new world was maintained by common expressions of religion such as the "Negro spirituals", one of the origins of the jazz which has had such a strong influence on popular music throughout the world ${ }^{6}$.

Another version holds that "Negeitude" was created in the 1930s by Aime Césaire, the famous French speaking Negro poet, but this anti-assimilation movement was soon taken up by the French-speaking West Indian Negroes and black Africans living in Paris. They were, Leon Damas from the West Indies, and Senegalese Leopold Sedar Senghor, Birago Diop, Keita Fodeba and Camara Laye of Guinea, the novelist Bernard Dadie and the dramatist Cofi Gadeau of Ivory Coast. However, the take home message is the fact that through its congresses in Paris in 1956, Rome 1959 and Dakar in 1966, "Negritude" achieved much against assimilation, especially as it received impetus even from a number of whites like the French writer; Jean Paul Sartre who joined these writers, artist and many other African professionals to express the African cultural values in poetry, drama, music and

\footnotetext{
${ }^{1}$ Victor Julius Ngoh, (1989), The World since 1919, A short history, Pioneer publisher, Yaounde, pp. $280-282$.

2 Ibid. p. 282

${ }^{3}$ Ibid.

${ }^{4}$ Gabriel de Bellescize, (1999), "Le maintien de la paix en Afrique: La France et le programme recamp" in Dossier Afrique de l'Ouest, Afrique contemporaine, No. 191, $3^{e}$ trimestre, p. 7.

${ }^{5}$ J.B. Webster, A.A. Boahen, H.O. Idowu, (1975), The growth of African civilization. The revolutionary years of West Africa since 1800 , London, Longman, pp. 274-275.

${ }^{6}$ Ibid. p. 75.
} 
novel $^{1}$.

But what we decry here is the fact that instead of embracing, pampering, orienting and adding more flesh to this movement, "Negritude" was criticised by many Africans, mostly those of the English-speaking Africa, regarding it either as sheer nonsense or as waste of time. For example Wole Soyinka, the well-known Nigerian playwright ridiculed it as he said;

"A tiger does not proclaim its tigritude. In other words, it is undignified to draw attention to what is always obvious. This is a wrong assumption when it is considered that even now many people especially those of European descent still deny the African contribution to civilisation. What is wrong with Negritude is not that it proclaimed the values of African civilisation. It was necessary to proclaim them to a world which denied their existence and used this denial to justify political and economic domination but rather that Negritude is now out of date".

According to Soyinka, Africa has made a great impact on the political world and researches in African studies since the 1950's. History, archaeology and anthropology has revealed so much about Africa and her past and is no longer necessary to continue to protest the cause of African civilisation.

Nevertheless, one may be tempted to give a reason to the useless criticisms against the French assimilation by the English speaking Africans because the British colonial rule did not attempt cultural assimilation. But in criticising this concept, the English-speaking Africans failed to understand that this movement was still part of the struggle for independence. Instead of rallying forces with this movement, British occupied territories of West Africa, went ahead to create the West African Students' Union (WASU) in the 1920s by Ladipo Solanke of Nigeria. WASU became the centre of political and social activities in which modern militant nationalism was born ${ }^{2}$. Instead of federating their efforts against this common manipulator, we still witnessed another theatre of Africans fighting Africans. If French and British African colonies had militated their forces from the start, the fight for and the achievement of independence would not have been too long and cumbersome because the movement for nationalism would have been a force to reckon with. This habit of African moving in disperse ranks was also very visible in the struggle for pan Africanism.

\section{II.2. African divers views and approaches over Pan Africanism}

Pan Africanism is a worldwide movement aimed at encouraging and strengthening bonds of solidarity between all indigenous and diasporan ethnic groups of African descent. It seeks to serve as a cultural and political ideology for the solidarity of all Africans. This is to connect and understand the universal injustice within the diaspora. To do this, founders of this ideology sorted and operated in the form of congresses. As an instrument for decolonization of Africa and the West Indies, the manifesto of the congresses demanded the end of colonial rule, racial discrimination, imperialism and the need for human rights and equality in economic opportunity. So far some of these congresses were held in Paris in 1919, London in 1921 and 1923, New York in 1927, Manchester in 1945, Dar es Salaam in 1974, Kampala in 1994 and Johannesburg in 2014. Though pan Africanism is based on the belief that unity is vital to economic, social and political progress and aims to unify and uplift Africans, exponents of pan Africanism as usual lacked the sense of a common direction to secure this unity for the people of Africa. Examples picked randomly from the second and fifth pan African congresses shows African discords instead of unity for the liberation of this continent.

The second pan African congress of 1921 was represented by twenty six different groups of Negro descent: British Nigeria, Gold Coast and Sierra Leone, the Egyptian Sudan, British East Africa, former German East Africa, French Senegal, the French Congo and Madagascar, Belgian Congo, Portuguese St Thome, Angola and Mozambique, Liberia, Abyssinia, Haiti, British Jamaica and Grenada, French Martinique and Guageloupe, British Guiana, the Unite States of America, Negroes resident in England, France Belgium and Portugal and fraternal visitors from India, Morocco, the Philippines and Annam. Though the congress created awareness of the fact that colonial problems must be solve by action in Africa itself not by political maneuvering in European capitals, delegates however did not agree on the method of pan Africanism and rout to independence ${ }^{3}$.

The French-speaking African delegation led by Blaise Diagne and Gratien Candace; representatives of Senegal and Guadeloupe respectively in the French chamber of Deputies soon abandoned the idea of pan Africanism, because they did not abide to the congress' demand for self-rule for Africans. This group saw their interest in the French union jeopardized if Africa was going to be given total independence. To that effect, they advocated for equal rights within the French union and consider the London manifesto declaration too dangerous and extreme ${ }^{4}$. The selfish ambitions of these French Africans led to their withdrawal and non-participation in subsequent pan African congresses.

This crack of African nationalism continued to deepen at the fifth pan African congress of Manchester in

${ }^{2}$ Ali A. Mazrui \& Michael Tidy, (1984), Nationalism and New States in Africa, London, Heinemann, p. 21.

${ }^{3}$ Ibid. p. 21-22.

${ }^{4}$ Ibid.
} 
1945. During this congress, instead of two stands at the previous congresses, there were four main strands of African nationalist that attended this congress. There was the indigenous stand which wanted African nationalism to go back to its pre-colonial period. This brand of nationalist led by Jomo Kenyatta, numerically dominated the congress and was manned by black nationalists who settled in England.

The second main group for African nationalism in this congress was the black American racial consciousness and political discontent which had grown up under slavery and gained strength after emancipation from continued white racism and continuing economic exploitation. The black consciousness in the New World was championed by Marcus Garvey and W.E.B. Du Bois, with the slogan "Africa for Africans". They wanted political independence of the African personality, cultural regeneration, a united African union government and the return of blacks of the diaspora to Africa ${ }^{1}$.

During this conference, nationalists' ideologies as to how Africa was to achieve sovereignty was a bone of contention, with those from the United States opposing their compatriots from London. Du Bois opposed Garvey's racial exclusiveness and stressed a world wide struggle of all oppressed, underprivileged, coloured people everywhere for freedom and justice.

The third stand was European socialism and communism which influenced those who studied in Europe and America like Leopold Sedar Senghor, Felix Houmphouet Boigny and Kwame Nkrumah respectively. Even flag bearers of this delegation could not agree on the road to independence for Africans. Communists demanded the forceful overthrow of colonial rule in the interest of world revolution. On its part, socialists favoured the advance of socialism by peaceful persuasion through parliamentary government. It is true that both parties were opposed to colonialism but communist wanted a violent and immediate independence while socialists opted for a gradual and peaceful decolonization of Africa ${ }^{2}$.

The fourth and last stand of African nationalism at the fifth pan African congress was the Gandhiism, the passive resistance principles which were less significant to Africans than the example of mass resistance in India and the practical effort to achieve self-determination. Looking at the above stands, these nationalists did not agree on the method of securing independence for this continent. Some of the delegates were very impatient at the gradualist approach to self-determination of the pre-war period and the emergence of Africa for Africans. Such exponents made it clear that; "We demand for black Africa autonomy and independence. The demand was no longer for improvements within the colonial system, but there was a new determination to do more than just pass resolutions. "We will fight in every way we can for freedom, democracy and social betterment" 3 .

These delegates argue that violence was a legitimate method of the struggle against colonialism. One of their resolutions reads; "The delegates to the fifth pan African congress believe in peace. How could it be otherwise when for centuries the African peoples have been victims of violence and slavery? Yet if the western world is still determined to rule mankind by force, then Africans as a last resort may have to appeal to force in the effort to achieve freedom, even if force destroys them and the world"4

We also noticed the almost complete absence of French African participation. This happened partly because of language difficulties but mainly because the French African nationalists were at this time heavily communist, Even Felix Houmphouet Boigny, later president of pro-West and free enterprise Ivory Coast was a communist in 1945 and being communist, they were pan-working class rather pan-African. They were also very heavily involved in French working class politics and were attached to French parliamentary institutions and the "évolué" philosophy. They wanted to achieve French citizenship for Africans rather than independence 5 .

This dichotomy of African nationalism created a hull in the steps towards African nationalism. From this conference, no pan African congress was held until 1958, when Nkrumah organized the All-African people's conference in Accra-Ghana. During this period, the division became more eminent as nationalist leaders concentrated on the struggle for individual African territories and ignored pan African federalism, a tool which would have been used to mount pressure on the west to liberate this continent.

According to Jacques Thombie and Co, these ideological differences, organizational separation and boycotts between French speaking and English speaking African leaders made them to by-passed key words like independence of colonies and decolonization. This word independence was employed for the first time by Union syndicale des travailleurs de la métallurgie on the $11^{\text {th }}$ November 1945 while the word decolonization came into use in $1952^{6}$. These blind and fruitless arguments on the part of Africans continue throughout and even today. The division of African leaders is a tragedy because it has given an advantage to western powers to continue to manipulate, exploit and still the wealth of this continent at the detriment of generations to come.

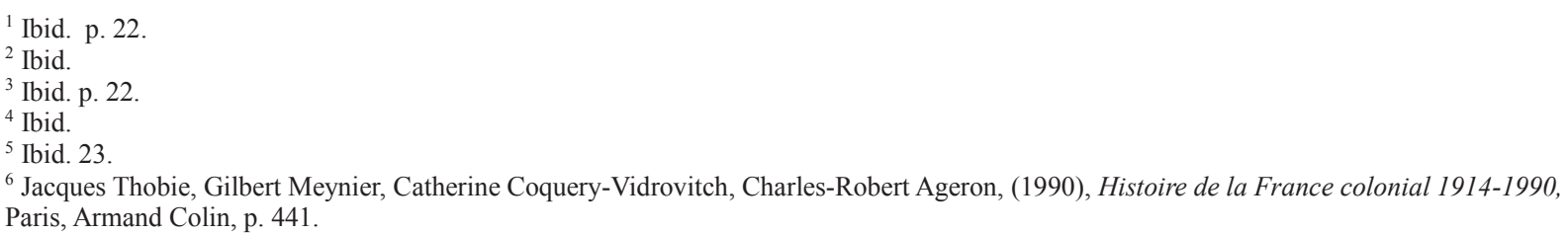




\section{II.3. Africans against African unity}

There is no way Africans can be exonerated from the ills that befall the continent. It is true that colonial powers in Africa contributed to the disunity in Africa. They created about 40 colonies with most of them smaller than some pre-colonial African states, introduced the divide and rule system and encouraged ethnic rivalries within African states. But all these and other pains inflicted on the entire continent did not ring any bell in the heads of the African political class. The complicity of African nationalist leaders backed by selfish attitude helped to divide this continent the more and prepare a bed for neo-colonialism in Africa.

In French West Africa, the Ivorian leader Felix Houphouet-Boigny griped with the fear that the wealth of Ivory Coast was to be used to subsidized poorer states, did all to see the abortion of the proposed West African federation. To that effect, Senghor accused him of being an instrument of France in balkanizing Africa. In the battle between Senghor (federalism) and Houhpouet (territorialism), it was the latter, backed by France who won, thus frustrating early chances of unity in French West Africa ${ }^{1}$.

In British West Africa, it was the leaders of the new African states and not the British who break up common services such as the British West African Currency Board, the West African Airways Corporation (WAAC), the West African Cocoa Research Institute and the West African Court of Appeal2 ${ }^{2}$.

In British East Africa, the scenario was the same. Though the new rulers developed a High Commission in the late 1960s but the east African community collapsed in the 1970s. Like in the west, there were rival African territorial nationalisms that became a factor of tearing the continent apart instead of federation. Leaders like Kwame Nkrumah and Sekou Toure, with their Ghana-Guinea union and Julius Nyerere with his proposal to delay Tanganyika's independence to coincide with joint independence for Uganda and Kenya so that an East African federation could be created. With this, we agree with Ali A. Mazrui \& Michael Tidy that the partition and the numerous troubles of Africa cannot solely be put on the shoulders of colonial rulers ${ }^{3}$. This following except gives a clear snap shot of the situation;

La décolonisation se trouve bloquée, et pas seulement au sud de l'Afrique, ou par les portugais. Le néocolonialisme n'est pas exclusivement d'origine extra-africaine. Au soudan, toute la région peuplée de noirs, au sud du dixième parallèle, est restée en dissidence de 1955 à 1972, après que l'Équatoria Corps se révolta pour exiger l'autonomie de cette zone. Les morts se compteraient par centaines de milles parmi les noirs animistes ou chrétiens, qui y ont été toujours exploités par les Arabisés ou Nubiens musulmans du nord ; c'est n'est pas pour rien que Khartoum signifie défense d'ivoire, car elle vécut de ce commerce du sud.

Au Burundi, des centaines es de paysans meurent de faim chaque année. Mais pour la caste dirigeante théocratique, les grands Tutsi et leur chef, le Mwami, Kigéri, qui hantait les bars de Genève, d'origine Nilotique, ce ne sont jamais des Hutus, des petits Bantous, parfaitement méprisables : des êtres réellement sans valeur, pour ces aristocrates du bétail. Après une tentative de révolte, 6000 de ces Hutus y auraient été exécutés. Le massacre reprend en 1973.

Au Rwanda voisin, ce sont ces Hutus qui ont pris le pouvoir : un peu par surprise, un aidés par les Belges, qui s'étaient d'abord appuyés sur le seuls Tutsis. Ces derniers fut alors massacrés, à raison de peut-être 15 ou 20000; tandis que 100000 d'entre eux fuyaient ce pays, devenu pour eux inhospitalier.

Les massacres du Congo Kinshasa sont un peu plus connus, car ils ont eu les honneurs de la presse occidentale. Mais pour celle-ci, la vie d'un rebelle congolais n'a guère de valeur, en comparaison de celle d'un missionnaire, ou d'un technicien Belge. Enfin, ces dernières années, l'horrible guerre civile du Biafra, ces femmes et enfants qui meurent de faim par centaines de mille : drame qui justifie- bien malheureusement- le titre de ce livre.

La notion même d'Etat centralisé reste ignorée de la grande majorité des africains. Il leur faudrait essayer de surmonter leurs différends, avant de pouvoir envisager la construction de l'unité africaine. Espérons qu'il leur faudra payer cette édification d'u prix du sang un peu moindre que le coût de l'unité européenne, qui s'esquisse seulement... ${ }^{4}$.

The above quotation is enough prove that some Africans were and are against any form of unity in the continent. They did and are still doing all to frustrate any spirit of unity.

\section{Dictatorship and chronic corruption of African leaders.}

As the title indicates, we will be looking at some acts of suppression and corruption perpetrated by African leaders and the elite class.

\footnotetext{
${ }^{1}$ Ali A. Mazrui \& Michael Tidy, Nationalism and new states in Africa, pp. 67-78.

${ }^{2}$ The British West African Currency Board established in October 1912 was responsible for the production and distribution of currency in the Cold Coast, Nigeria, Sierra Leone and Gambia in line with the gradual movement towards the independence of British occupied territories in West Africa.. The West African Airways Corporation was an airline created in 1946 and jointly owned by the governments of the above four British West African colonies. The West African Cocoa Research Institute was created as the central cocoa research station at Tafo in 1938 by the Gold Coast department of agriculture to investigate problems of diseases and pests which had reduced cocoa production in the eastern province. The West African Court of Appeal was established in 1867 as an appellate court for British possessions in West Africa.

${ }^{3}$ Ali A. Mazrui \& Michael Tidy, Nationalism and new states in Africa, p. 67

${ }^{4}$ René Dumont, L'Afrique noire est mal partie, Imprimerie Bussière, Saint-Amand, pp.93-94.
} 


\section{III.1. Dictatorship of African leaders}

After independence, most African head of states became tyrants, suppressing any form of political ambition with contrary ideas. Therefore, we will be looking at some of the repressive acts like the concentration of power and the abuse to multi-particism as an element of democracy. In respect to the concentration of power, African leaders centered everything on them, family members and friends. In Guinea for example, power was in the hands of Andrée; the first lady, Ismaël, Siaka; the brother of Sekou Toure, his nephew and many others. These were the people pronouncing and executing prison and dead sentences against those who opposed President Sekou Toure. The nature of the political tension in this country could be felt from the first words of hope after the departure of Sekou Toure on the $26^{\text {th }}$ March, 1984; "La fin d'une dictature sanglante entretenue par la féodalité de famille et l'influence de son compagnons malhonnêtes, la promesse d'une démocratie véritable qui saura se garder à l'avenir de la confiscation du pouvoir par un seul homme". In order to enable us live the situation, Mohamed Selhami paint a picture of the horrible conditions in one of the concentration camps called dead factory, commanded by Mamadou Boiro as seen in the picture below.

\section{Pictures 1: Mamadou Boiro's concentration camp in Guinea Conakry (1971)}

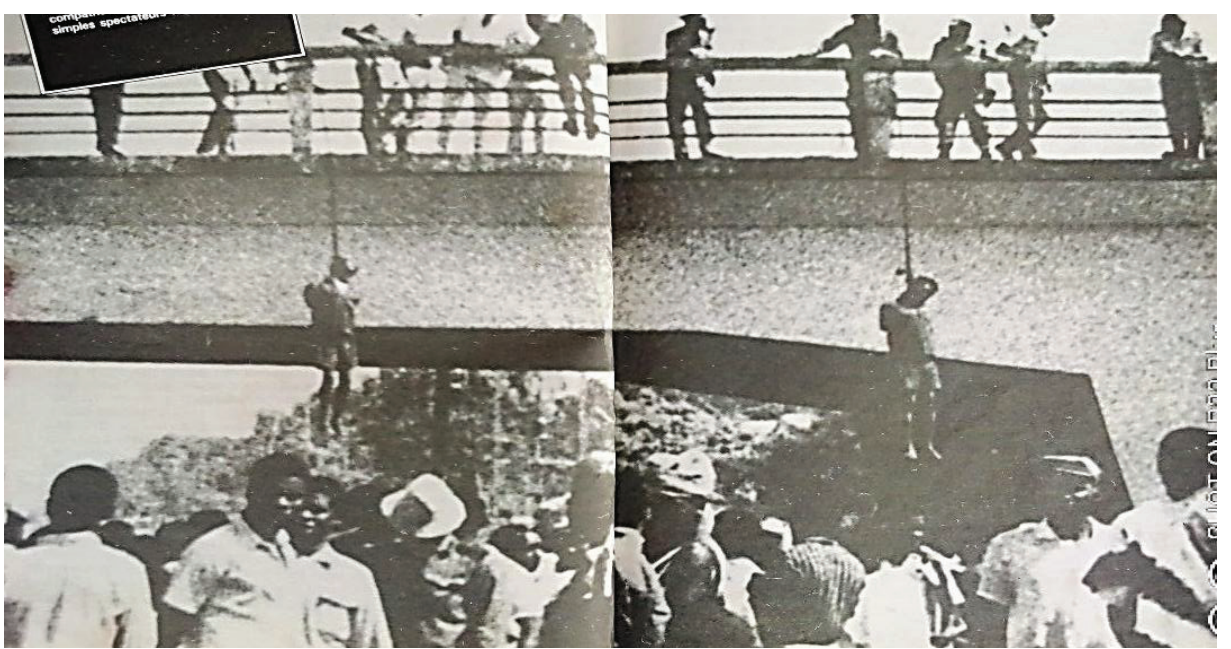

Source: Jeune Afrique Plus, Paris, 1984, pp. 36-37.

The above prison is one of the numerous prisons that haboured political rivals of President Sekou Toure. Once in any of these camps, one was never sure to join the family again. Guineans enjoyed some political freedom and total relief after such a leader ${ }^{2}$. To help maintain them to power, African leaders went back to sign treaties with their colonial masters in order to ensure their stay in power as long as possible. These dictators formed a group of harmonious friendship at the Organization of African Unity and were not ready to welcome any outsider. They make sure that no one come to power through a coup d'état and is accepted in this organization. For example, Julius Nyerere's support for Milton Obote who was ousted from power in Uganda through a military coup created tension within the Organization of African Union (O.A.U.) when Nyerere refused to recognized the new Ugandan government. Instead of preoccupying themselves with projects gearing towards the wellbeing of Africans, the O.A.U. fell short of the ideal of a United State of Africa anticipated by exponents of pan-Africanism but on how to consolidate power ${ }^{3}$.

As regard to the misuse of multi-particism as an element of democracy African leaders have created a multitude of unnecessary political parties. To them, democracy means the proliferation of political parties. In Nigeria for the example, there are more than five political parties base on regional boundaries. Some are the National Council of Nigeria and the Cameroon (NCNC) of Nnamdi Azikiwe base in the East, the Action Group of Chief Obafemi Awolowo in the West while the Alhaji Sir Abubakar Tafawa Balewa founded the Northern People's Congress ${ }^{4}$. Instead of bringing together their efforts against colonial malpractices, the Muslim north was afraid of the Christian south. Even the attempt made by the Richards constitution of 1947 to instill the spirit of nationalism by creating a legislative council that brought representatives of all the regions together was criticized by Nigerians. According to Chief Awolowo as sited by Tambi Eyongetah \& Robert Brain, amongst many other reasons condemned that "...in view of the diverse culture in Nigeria, it was anachronistic to have a unitary constitution in the country..." 5 . This move that was to foster the unity of the country received a slap because

\footnotetext{
${ }^{1}$ Sennen Andriamirado, (1984), L'avenir est arrivé le 3 Avril in Jeune Afrique Plus, Paris, pp. 5-6.

${ }^{2}$ Mohamed Selhami, (1984), Le camp Mamadou Boiro, l'usine de la mort, in Jeune Afrique Plus, Paris, p.32.

${ }^{3}$ Joseph Ki-Zerbo, Histoire de l'Afrique noire d'hier a demain, Paris, Hatier, pp. 644-645.

${ }^{4}$ J.D. Fage, An introduction to the history of West Africa, pp. 206-207.

${ }^{5}$ Tambi Eyongetah \& Robert Brain, A History of Cameroon, Hong Kong, Longman group Ltd, p. 124.
} 
leaders feared compromising their leadership positions.

In Cameroon, the situation is not better. Cameroon has over fifteen political parties. Some are; Cameroon People's Democratic movement (CPDM), led by Paul Biya, the Social Democratic Front (SDF) of Ni John Fru Ndi, Cameroon Democratic Union (CDU) of Adamou Ndam Njoya, Union of the Peoples of Cameroon (UPC), National Union for Democracy and Progress (NUDP) of Maigari Bello Bouba, Cameroonian Party of Democrats (CPD), Alliance for Democracy and Development (ADD) of Garga Haman Adji, Movement for the Defense of the Republic (MDR) Dakole Daissala, Cameroon Reformation Party (CRP) by Foligar Kum Lang, Republican Party of Cameroon, (RPC) of George Gilbert Baongla. There is also African Peoples Union (APU) led by Hubert Kamgang, Progressive Movement (PM) by Jean-Jacques Ekindi, Believe in Cameroon ((BC) of Bernard Njonga, Cameroon Renaissance Movement (CRM) of Maurice Kamto, Cameroon People's Party (CPP) of Edith Kah Walla, Movement for the Liberation and Development of Cameroon (MLDC) of Marcel Yondo, Cameroon Party for National Reconciliation (CPNR) of Cabral Libii. In Benin, there are about 44 political parties, about 102 in Burkina Faso and the list continues.

These parties are drawn on tribal and or regional lines. For the example in Cameroon, if someone say SDF, what comes to the mind first is the North West and South West or West Cameroon, CDU or CRM, one will think of the West, UPC is base in the Littoral, NUDP or ADD one will think of the North and so on ${ }^{1}$.

Africa is the only continent in the world that is gifted in the fabrication of political parties, with most of the parties being satellite parties created by the ruling party to dilute, weaken, destabilized and frustrate main stream opposition parties. Indeed the multiplicity of political parties with diverse political slogans, ethnic inclinations, political immaturity of leaders, unrealistic political ambitions and projects have live the masses perplex on the choice of political leader and party to follow. This, all what we have elucidated above and many other irresponsible behavior of Africans not mention here have contributed to render this continent fragile and vulnerable to the western world. This situation was aggravated by corruption.

\section{III.2. Chronic corruption of African elites}

Corruption of African leaders is one of the root causes of the underdevelopment of Africa. This ill is manifesting in different forms. It ranges from siphoning state funds, egotism, tribalism and many other acts of irresponsibility of these leaders. Many African elites after independence took the place of the white man in the continent, benefited so many advantages, exorbitant salaries, luxurious cars and villas, with many of them embezzling billions from state coffers. Rene Dumont accuses countries like Nigeria, Central African Republic, Congo, Gabon, Ivory Coast, Dahomey, Cameroon, Equatorial Guinea and many others ${ }^{2}$.

In Cameroon, the Yaounde central prison (Kondengui prison) has a section full of such elites commonly called luxurious prisoners. This embezzlers most often swindled funds up to about 10 percent of the national budget. With these funds and administrative powers, they have done everything to ensure that their children and family members are enrolled into all strategic administrative institutions to ensure continuity in leadership and domination in the management of state affairs. Some of these institutions are the National School of Magistracy and administration (ENAM), Cameroon Institute of International Relations (IRIC), Inter Army Military Academy (EMIA) and many others. Access into these prestigious institutions is not meant for the intellectuals but for the well-to-do. It is not strange to hear that the dead succeeds entrance exams into such institutions in Cameroon ${ }^{3}$.

Similarly, Angola had lost control over billions of dollars from its sovereign wealth fund. The money was siphoned by a rogue fund manager and other complicit, through complex financial transactions moving through offshore financial centers and invested in ventures of personal interest. The new Angolan government elected in 2017 changed the management and placed the previous management under investigation. All these at the detriment of tax payers and intellectuals since mediocrity has dominated meritocracy. The blame for the inability of most African leaders to put an end to such practices which crumble the state and cause underdevelopment cannot be shoulder by the West but by Africans.

African leaders are very self-centred and tribalistic. They preferred companions (friends and relatives) who will help them sail through their egoistic ambitions than technocrats. Even if some technocrats were appointed, these companions had more powers than any of them. Take the case of Ahidjo, with many of his ministers and collaborators coming from the North and many other cases like that of Sekou Toure of Guinea, Nkrumah of Ghana, Robert Mugabe of Zimbabwe and many others ${ }^{4}$

African leaders have connived with colonial powers to rob this continent off its wealth. To backup this assertion, Achille Mbembe, with the case of France, demonstrate how Europeans have established a vast system

\footnotetext{
${ }^{1}$ Nelson Sobrinho, (2019), retrieved from http://www.imf.org VIMAL THAKOOR; Tackling Corruption in Sub-Saharan Africa, in IMF Finance and development Magazine, consulted on 05/05/2020, at 4:44pm.

${ }^{2}$ René Dumont; L'Afrique est mal partie, p. 77.

${ }^{3}$ Nelson Sobrinho, (2019), retrieved from http://www.imf.org VIMAL THAKOOR; Tackling Corruption in Sub-Saharan Africa, in IMF

Finance and development Magazine, consulted on 05/05/2020, at 4:44pm.
} 
of immunities base on reciprocal assimilation and mutual corruption of African elites.

...Françaises et africaines, elle sera régie par toutes sortes d'arrangements privés et de passedroits et huilée par des pratiques illégales, voire criminelles. Pour sa survie, ce système dépendra de la permanence de forme de pouvoir tyrannique en Afrique et d'une patrimonialisation de la politique africaine de la France soustraite à tout contrôle démocratique et parlementaire.

Grâce à ce système, les potentats africains jouiront d'une large autonomie vis-à-vis de leurs peuples, devant lesquels ils ne seront guère comptables. Des accords secrets et inégaux feront des satrapes africains des vassaux au sein d'une vaste toile informelle affixée à l'État français. Au centre de cette toile trônera le chef de l'État français. Il sera relayé par ses courtisans, ses émissaires, une panoplie d'officines dans lesquelles se mêleront affairisme, renseignement policier et militaires, toutes sortes de faveurs, et où, de temps à autre, l'on décidera de quelques assassinats ciblés. Pour jouir de la protection assurée par le suzerain, les potentats africains se déchargeront en retour d'aspects cruciaux de la souveraineté de leurs Etats sur les plans militaires, monétaire et idéologique. Pour certains, ce cycle historique, désormais privé des ressources de sa reproduction sur la longue durée, arrive à sa fin. Pour d'autres, la pieuvre est loin d'être morte'.

To that effect, Achille Mbembe called on Africans to unanimously stand up not only against such wayward Africans lacking the sense of patriotism but also to put an end to the spirit of cultural racism, paternity and mercantilism in this continent ${ }^{2}$. Therefore, for Africa to come out of this mess, something must be done.

\section{The way out}

This work will not be complete without recommendations for the way forward. All is not lost. There is every reason to hope for a brighter Africa and from our analysis, a solution to the African problem is more of political though socio-economic too.

\section{IV.1. Political consistence.}

The key for the way out of African dependency, exploitation and domination is first political. Africans must have a political will and consistency. There must be an inter-African mutual defense pact and not antagonistic pacts. This will make collective security in Africa indivisible. We are conscious of the fact that it is very difficult for some African countries to relinquish part or all of their sovereignty but as Ki-Zerbo will put it, there can never be a united Africa without the sacrificing of sovereignty and without association at the level of mass organizations. To obtain African unity, leaders must be prudent, realistic and courageous ${ }^{3}$. The development of Western Europe accentuated when its administration attained a certain degree of honesty. Therefore, there is the need to detect young, talented, honest and courageous African leaders who will be devoted to the general interest of the continent. They will not only stamp out corruption but also to provoke economic and political evolution that will give Africa a new face lift ${ }^{4}$.

This new generation must take as a responsibility to reduce the gap between the urban and the rural areas in Africa. The different African governments, especially those of Africa south of the Sahara must endeavour to bridge the gap between the urban and the rural areas. As of Jean Marc Ela, African leaders should move out of the centralized system of government inherited from colonialism as exalted in the following except;

“...il faut renoncer à la centralisation héritée du colonialisme. Les élites africaines ont assume cette centralisation comme une des composantes dans la métropole, et, en conséquence, l'immobilisme et le mépris dans lequel le reste de la région est plonge. L'idéologie coloniale, reprise sans grand changement par les classes dirigeantes à l'époque de l'indépendance, consiste à attendre des institutions centralisées importées d'Europe des éléments susceptible les de faire émerger un état moderne, avec un capitale digne de ce nom. Le model urbain imposé à l'Afrique par la colonisation présuppose un schéma centralisateur qui donne le primat à l'administratif ; ce schéma conduit à l'émergence d'une bourgeoisie de la fonction publique qui concentre dans la capitale les rouages indispensables au fonctionnement de l'état jacobin. Conditionné par ce modèle, les classes dirigeantes ont repris et accentué ne armature urbaine... ${ }^{5}$ ".

This situation has given the right to those who already scented a problem and thought that independence was going to benefit only some particular people. As sited by Rene Dumont, some Africans of Congo Brazzaville at the dawns of independence argued that; [L'Independence, ce n'est pas pour nous, mais pour les gens de la ville]. Besides, in October 1961, the Mayor of Nkongsamba in Cameroon declared to prime minister Assale that; [La masse a l'impression que la souveraineté nationale a créé une classe de privilégiés qui se coupe d'elle...nous

\footnotetext{
${ }^{1}$ Ibid.

${ }^{2}$ Achille Mbembe, (2013), “Ce qui doit changer” in Jeune Afrique, No. 2760 du $1^{\mathrm{er}}$ au 7 Décembre, p. 78.

${ }^{3}$ Ibid. p. 649

${ }^{4}$ René Dumont; L'Afrique est mal partie, p. 88.

${ }_{5}^{5}$ Jean Marc Ela, (1983), La ville en Afrique Noire, Editions Karthala, paris, pp. 198.
} 
tendons vers un pire colonialisme de classe $]^{1}$.

The concentration of the wealth of the continent in the hands of very few elites and all amenities in urban areas has greatly hindered development in this continent. This has not only make Africans life beggars and dependent on the west but is the umbilical cord of the numerous crises observe in the continent. A situation that has brought Francis Soudan to question the sovereignty of Africa as seen in this rhetoric question, L'Afrique existet-elle? He observed that Africans north and south of the Sahara are looking at opposing directions and that the only thing bringing Africans together is language. The continent is now regrouped into three blocs; francophone, Anglophones and Lusophones, with a wide gap between the rich petrol and mineral nations and the poor nations ${ }^{2}$.

As a remedy to crises in Africa, Africans have to sit round a table to discuss measures of peace and security in Africa and not allow colonial mongers like France in the case of French-African summits to pretend to do so. According to Chris Jackson, this is one of the reasons for which the Rwandan President, Paul Kagame, does not see any need to attain the African-French summit. Africans north and south of the Sahara have to look at the same direction ${ }^{3}$.

On his part, Gabriel de Bellescize think that Africans must simply understand and reason like one, knowing that the cause of all these territorial disputes is as a result of irrational and artificial colonial frontiers as well as poor governance in Africa. Besides, African leaders must learn to create an enabling environment to avoid ethnic and religious conflicts ${ }^{4}$

Eric Bonnemasion comes in to emphasize the need to rebuild security in Africa after all. Security must become a public utility in this continent, he insisted. According to him, this will provide a favourable political atmosphere by restoring a monopoly of public force to African states and obliging these states to be accountable to the people, with the army and forces of law and order becoming a value added for the population and not for the government. African leaders must ensure justice to all, taking into consideration the poor, orphans, widows, unemployed and many others, assure equitable distribution of natural resources and financial transparency ${ }^{5}$. If this is done, the wind of inter-tribal wars and inter-state conflicts will be over.

\section{IV.2. Social modernization.}

As a solution to the development of Africa, Rene Dumont strongly proposed that Africa must rethink of its education, personnel, its structure and many others. Such a determine class of Africans mentioned above must go out of what this author call "L'Ecole des certifies-chomeurs et les paysans sans cadres". By this, he is referring to education which is purely academic, with peasants, farmers, technicians having no say. This kind of education is not only cut off of the realities and needs of Africans but also very costly to the state. For example, in Niger, it consumes about 24 percent of the national budget. African leaders must lay emphasis on a firm rural school program, very modest and modern, adapted to the existing labour ${ }^{6}$.

This can be possible only if African governments click to what Joseph J. Spengler title; pillars of modernization. According to this author, African governments must give more impetus on fixed capital. There must be adequate investment in the development of scientific knowledge and in the application of both this knowledge and that obtainable from the accessible world pool of knowledge to which many nations contribute. The education and the quality of the population must be kept abreast of changing industrial and professional requirements that largely reflect improvement in technology. The supply of foodstuffs and raw materials must remain sufficiently elastic and the need for a flexible price system that assembles and communicate information regarding cost, supply and demand situations and thus facilitates relatively optimum use of the nation's resources, given something like the current pattern of income distribution ${ }^{7}$.

With regards to African health problems, Gottlieb Lobe Monekosso \& Ejomi Martin Gladys in Principles and practice of community health, proposed a roadmap journey to health for all Africans. African countries must adopt, develop explicit health policies, strategies and action plans consistent with achieving health for all through primary health cares 8 . The World Health Assembly in 1977 recommended "Health for all" by the year 2000. This institution called for all countries to develop a level of health that will permit them to lead socially and economically productive lives. This should be by ensuring better health conditions in homes, schools and factories because it is

\footnotetext{
${ }^{1}$ René Dumont ; L'Afrique noire est mal partie, p. 5.

${ }^{2}$ François Soudan, (2013), L'Afrique existe-t-elle ? in Jeune Afrique No. 2760 du $1^{\text {er }}$ au 7 Décembre, p. 6.

${ }^{3}$ Chris Jackson; in Jeune Afrique No. 2760 du $1^{e r}$ au 7 Décembre, 2013, p.10.

${ }^{4}$ Gabriel de Bellescize, (1999), "Le maintien de la paix en Afrique: La France et le programme recamp" in Dossier Afrique de l'Ouest, Afrique contemporaine, No. 191, $3^{e}$ trimestre, p.10.

${ }^{5}$ Eric Bonnemasion, (2001), Refaire de la sécurité en Afrique un bien public, in Dossier Afrique de l'Ouest, Afrique contemporaine, No. 200 ,

$4^{e}$ trimestre, pp.3-6.

${ }^{6}$ Ibid. pp. 154-155.

${ }^{7}$ Joseph J. Spengler, (1966), Modernization : The Dynamics of Growth, Cambridge, Mass, p. 352.

${ }^{8}$ Gottlieb Lobe Monekosso, (1992), Working for better health in Africa, Experiences in the management of change, World health Organization, Regional office for Africa, Brazzaville, November, p. 12.
} 
hear that health is made or broken. So to say the key to achieving health for all is primary health care ${ }^{1}$. It is true that African health services grew from the colonial medical services developed primarily for the army and colonial service officers. But it has been extended to local civil servants, relatives and to neighbouring population while rural areas, the most vulnerable are almost abandoned to voluntary and religious organizations. Therefore, policy makers in the health sector; the minister of public health, its decentralized agencies and all health institutions and professionals must put their hands on deck to detect health care needs as well as adopt appropriate health care technologies ${ }^{2}$.

Jean Marc Ela is strongly of the opinion that reducing the gap between the urban and the rural areas in Africa can be by improving on the urban-rural communication infrastructure, the provision of portable water and rural electrification, bring medical facilities closer to the population ${ }^{3}$. Of all these, Maryse Gaimard declared that health is the most essential for human and societal development, pointing out that it is the cause of the emergence of Asian countries, contrary to those of Africa as he said; "Parmi tous les facteurs qui expliquent la divergence d'évolution depuis le début des années 1950, entre les pays asiatiques qui ont émerge et les pays d'Afrique subsaharienne, les plus pauvres, la santé ressort très nettement ${ }^{4}$ "

\section{IV.3. Economic complementarity.}

To add more substance to the above prescriptions, many authors are of the opinion that there must be economic revival of this continent. Ki-Zerbo proposed that Africans must opt for economic complementarity. Economically giant African states must conspire with micro states with little or no economic future ${ }^{5}$. African leaders are noted to be responsible for the indebtedness of the continent in general and their countries in particular. Most often, they borrow money to buy luxurious cars and or engage other unproductive projects. Sometimes the funds are swindled on transit into personal accounts. It is worth noting that these loans and aids are at the detriment of the independence of the nation concern. Patriotic African leaders are therefore exalted to resist any kind of foreign aid or loan. If need be, accept such aids but refuse any political subordination. Secondly, such loans must be directed towards long term productive investments like infrastructure, education, vocational training, and industrial equipments for agricultural modernization ${ }^{6}$.

In the same light, Foutem Thierry-Martin affirmed this by remarking that African dependency is due to its indebtedness and therefore, is of the opinion that African leaders must put into place national projects for collective awareness, valorize local development through the promotion of indigenous values as well as reinforce and promote south-south cooperation in order to destroy dependency on aids ${ }^{7}$. A rich country or continent can easily defend itself. Africa must achieve economic independence. It is obvious that the road is very long but it is not inaccessible. To get to its destination, African leaders must form a common front against the imposition of political conditions as a prelude of obtaining financial assistance.

From an economic perspective, there are some basic principles that apply across countries and can boost governance. These are strengthening laws, improving government effectiveness and shoring up fiscal and anticorruption institutions. African governments should emulate the example of Botswana, Chile, Estonia, and Georgia that have managed to lower corruption by simple political will and other measures like cutting the red tape and lowering trade barriers, putting into place an independent judicial system, a strong anti-money laundering framework, improving fiscal institutions with greater transparency and controls. Building expertise and empowering employees in institutions designed to fight corruption will improve their prosecution capability and bridge the gap between public opinion and the court of law. Corruption prosecution cases often fail when governments lack adequate legal capacity. Enhancing corporate governance and a system of checks and balances, particularly through a better governance structure for state-owned enterprises, will also help ${ }^{8}$.

If this is done, it will enhanced revenue collection through improved tax compliance, since customs and revenue authorities are better able to combat smuggling and illicit flows when tax officials adhere to strong governance principles. Besides, citizens are more likely to pay their taxes when they trust the effectiveness of government spending. There will be more efficient government spending thanks to stronger budgetary processes. Good governance reduces the risk of harmful shifts in government spending toward items subject to graft like white elephants, for instance. The country will witness improved developmental outcomes and social inclusion. More revenue overall means governments can spend more on their people. Improved governance is likely to benefit

${ }^{1}$ Gottlieb Lobe Monekosso \& Martin Gladys Ejomi, (2008), Principles and practice of community health, Yaounde, Edition cle, pp. 19-20.

${ }^{2}$ Ibid. pp. 34-35

${ }^{3}$ Jean Marc Ela; La ville en Afrique Noire, pp. 88-991.

${ }^{4}$ Maryse Gaimard, (2011), Population et santé dans les pays en développement, Paris, L'Harmattan, 2011, p. 7.

${ }^{5}$ Joseph Ki-Zerbo, Histoire de l'Afrique noire d'hier a demain, Paris, Hatier, 1978, p. 647.

${ }^{6}$ Ibid. p. 220

${ }^{7}$ Thierry-Martin Foutem, (2019), External aid to development and new form of colonization of Cameroon by its former metropolises (19602009), in Unfinished independence in Africa, Economic articulations of neocolonisation, Monange, Yaounde, pp. 37-38.

${ }^{8}$ Nelson Sobrinho, (2019), retrieved from http://www.imf.org VIMAL THAKOOR; Tackling Corruption in Sub-Saharan Africa, in IMF Finance and development Magazine, , consulted on 05/05/2020, at 4:44pm. 
the poor disproportionately as they rely more on social services. And increased spending on education and health supports economic and social inclusion and reduces vulnerability ${ }^{1}$

\section{Conclusion}

From our foregoing analysis, Africans are responsible for their underdevelopment, dependency, socio-political crises and many other ills that strike this continent. Be it during slave trade and slavery, colonialism or neocolonialism, they have in many occasions fail to think, speak and act like one. Africans have always faced their global challenges in disperse ranks or sometime fight with one another over little or nothing instead of a common enemy; western predators. Experience has proven that raids and inter-tribal wars in the continent between the $15^{\text {th }}$ and $19^{\text {th }}$ centuries triple because of slave trade. Some Africans felt very normal and confortable in capturing others and giving to European slave dealers for onward transmission to plantations in the Americas. Besides, power tousle, corruption and many other irresponsible acts canvass by western powers and piloted by Africans are proves that the African elite class put their interest at the forefront at the detriment of the wellbeing of a common African. This situation has most often than not live this continent at the mercy of the western world. It was African comportment that made European to state that Africa is a zone with no political structure where anarchy, high barbarism, animosity, slavery, ignorance and suffering were the order of the day. Though with a hidden agenda, Europeans profited to step in, with the pretext of bringing, civilization and progress to Africans. But the coming of Europeans into this continent has caused untold damage to Africans. They have paid and are still paying the prize of the European presence in Africa both in their flesh and their rich bio diversity. This is thanks to the collaboration of some Africans whom the Europeans and Joseph Ki Zerbo respectively described as non-nationalist and rabbits $^{2}$. It is very easy to accuse neo-colonialism of perpetrating Africa's underdevelopment. But then these Africans have a good chunk of the blame. They allied with colonialist for short-term gains, often of personal nature. According to Ali Mazrui and Michael Tidy, the real obstacle to African development is the apparent lack of will on the part of African leaders to tackle African problems ${ }^{3}$. As a solution to these problems, results of this research recommend African political consistence, social modernization and economic complementarity. Africans need to be supportive, learn to bury their hatchets especially in times of challenges, for the interest of all.

\section{References}

Ali A. Mazrui \& Michael Tidy, (1984), Nationalism and new states in Africa, Heinemann, London,

Bonnemasion Eric, (2001), "Refaire de la sécurité en Afrique un bien public", in Dossier Afrique de l'Ouest, Afrique contemporaine, No. 200, $4^{e}$ trimestre.

Dike K. Onwuka, (1956), Trade and politics in the Niger Delta, 1830-1885, London.

Dumont René, (1973), L'Afrique noire est mal partie, Imprimerie Bussière, Saint-Amand.

Ela Jean Marc, (1983), La ville en Afrique Noire, Editions Karthala, paris.

Foutem Thierry-Martin, (2019), "External aid to development and new form of colonization of Cameroon by its former metropolises (1960-2009)", in Unfinished independence in Africa, Economic articulations of neocolonisation, Monange, Yaounde.

G. de Bellescize, (1999), "Le maintien de la paix en Afrique: La France et le programme recamp" in Dossier Afrique de l'Ouest, Afrique contemporaine, No. 191, $3^{e}$ trimestre.

Gaimard Maryse, (2011), Population et santé dans les pays en développement, L'Harmattan.

Nelson Sobrinho, (2019), retrieved from http://www.imf.org VIMAL THAKOOR, Tackling Corruption in SubSaharan Africa, in IMF Finance and development Magazine, consulted on 05/05/2020, at 4:44pm.

Inikori J. E., (1999), 'L'Afrique dans l'histoire du monde : la traite des esclaves à partir de l'Afrique et l'émergence d'un ordre économique dans l'Atlantique" in Histoire Générale de L'Afrique; L'Afrique du XVI au XVIII siècle, Tome $V$, UNESCO.

J.D. Fage, (1966), An introduction to the history of West Africa, third edition, Cambridge University Press.

Ki-Zerbo Joseph, (1978), Histoire de l'Afrique noire d'hier a demain, Paris, Hatier.

Le Vine T. Victor, (1964), The Cameroons from mandate to independence, University of California Press, Los Angeles.

Lobe Monekosso Gottlieb \& Ejomi Martin Gladys, (2008), Principles and practice of community health, Edition cle, Yaounde.

Lobe Monekosso Gottlieb, (1992), Working for better health in Africa ; Experiences in the management of change, World health Organization, Regional office for Africa, Brazzaville.

Mbembe Achille, (2013), "Ce qui doit changer" in Jeune Afrique, No. 2760 du $1^{\text {er }}$ au 7 Décembre.

Ngoh Victor Julius, (1989), The World since 1919, A short history, Pioneer publisher, Yaounde.

Ngongo Louis-Paul, (1987), Histoire des institutions et des faits sociaux du Cameroun 1884-1945, tome 1, Berger-

\footnotetext{
${ }^{1}$ Ibid.

2 Joseph Ki Zerbo, Histoire de l'Afrique Noire d'hier a demain, p. 413.

${ }_{3}^{3}$ Ali A. Mazrui \& Michael Tidy, Nationalism and new states in Africa, p. 83.
} 
Levraut, France.

Selhami Mohamed, (1984), "Le camp Mamadou Boiro, l'usine de la mort", in Jeune Afrique Plus, Paris.

Sennen Andriamirado, (1984), "L'avenir est arrivé le 3 Avril”, in Jeune Afrique Plus, Paris.

Soudan François, (2013), “L'Afrique existe-t-elle ?” in Jeune Afrique No. 2760 du $1^{\text {er }}$ au 7 Décembre.

Spengler J. Joseph, Modernization: The Dynamics of Growth, (1966), Cambridge, Mass.

Tadeuz Lewicki, (1990), "Le rôle du Sahara et des Sahariens dans les relations entre le Nord et le Sud", in Histoire Générale de L'Afrique; L'Afrique du VII a a XI siècle, Tome III, UNESCO.

Tambi Eyongetah \& Robert Brain, (1974), A History of Cameroon, Longman group Ltd, Hong Kong.

Thobie Jacques, Meynier Gilbert, Coquery-Vidrovitch Catherine, Ageron Charles-Robert, (1990), Histoire de la France colonial 1914-1990, Armand Colin, Paris, 